\title{
Acetylcholine produces contraction mediated by cyclooxigenase pathway in arterial vessels in the marine fish (Isacia conceptionis)
}

\author{
Moraga, FA. ${ }^{a *}$ and Urriola-Urriola, $N .^{a}$ \\ ${ }^{a}$ Laboratorio de Fisiología, Hipoxia y Función Vascular, Departamento de Ciencias Biomédicas, Facultad de Medicina, \\ Universidad Católica del Norte, Larrondo 1281, Guayacán P.O. Box 117, Coquimbo, Chile \\ *e-mail: fmoraga@ucn.cl
}

Received: July 25, 2013 - Accepted: January 16, 2014 - Distributed: May 31, 2015

(With 1 figure)

\begin{abstract}
Preliminary studies showed that dorsal artery contraction mediated by acetylcholine (ACh) is blocked with indomethacin in intertidal fish ( $G$. laevifrons). Our objective was to characterize the cholinergic pathway in several artery vessels of the I. conceptionis. Afferent and efferent branchial, dorsal and mesenteric arteries were dissected of 6 juvenile specimens, isometric tension studies were done using doses response curves (DRC) for Ach $\left(10^{-13}\right.$ to $\left.10^{-3} \mathrm{M}\right)$, and cholinergic pathways were obtained by blocking with atropine or indomethacin. CRC to ACh showed a pattern of high sensitivity only in efferente branchial artery and low sensibility in all vessels. Furthermore, these contractions were blocked in the presence of atropine and indomethacin in all vessels. Our results corroborate previous results observed in intertidal species that contraction induced by acetylcholine is mediated by receptors that activate a cyclooxygenase contraction pathway.
\end{abstract}

Keywords: intertidal fish, vascular reactivity, acetylcholine, atropine, indomethacin, cycloxygenase.

\section{Função vascular nas artérias do peixe marinos Isacia conceptionis}

\begin{abstract}
Resumo
Estudos preliminares mostraram que a contração da artéria dorsal mediada por acetilcolina (ACh) é bloqueada com indometacina em peixes marinhos ( $G$. laevifrons). Nosso objetivo foi caracterizar a via colinérgica em várias artérias de I. conceptionis. Artérias aferentes e eferentes branquiais, dorsais e mesentéricas foram dissecadas de 6 espécimes juvenis. Os estudos de tensão isométrica foram feitos utilizando-se a curva dose - resposta (CDR) para Ach $\left(10^{-13}\right.$ a $10^{-3} \mathrm{M}$ ), e identificaram-se as vias colinérgicas, bloqueando com atropina e indometacina. CRC para ACh mostrou um padrão de alta sensibilidade na artéria eferentes branquiais e baixa sensibilidade em todos os vasos sanguineos. Essas contrações foram bloqueadas na presença de atropina e indometacina em todas as artérias avaliadas. Nossos resultados confirmam que a contração induzida por acetilcolina é mediada por receptores muscarínicos que ativam ciclo-oxigenase.
\end{abstract}

Palavras-chave: peixes marinos, reatividade vascular, acetilcolina, atropina, indometacina, ciclo-oxigenase.

\section{Introduction}

Physiological constraints are important determinants of the distributions limits of species and populations; however, processes associated with environmental tolerance explaining, at the local scale, differential habitat use or, species distribution patterns remain poorly understood. Indeed, latitude, altitude and depth all constitute gradients, which can generate physiological diversity. Among populations, variation in physiological traits can be environmental induced, through non-genetic, reversible mechanisms of phenotypic flexibility or acclimatization. In line with this, it is a transitory species Girella laevifrons (intertidal specie) that only inhabits these environments during the juvenile stage and later migrates to the subtidal zone (Pulgar et al., 1999). Intertidal fish represent a complex organism tolerated to extreme conditions in the microhabitats of pools during

low tide. Previous results obtained in our laboratory, performed in the dorsal artery in, showed a powerful vasoconstriction induced by acetylcholine mediated by cyclooxygenase (Urriola-Urriola and Moraga, 2008), furthermore, studies performed in several vessels such as dorsal, mesenteric, afferent and efferent branchial arteries in G. laevifrons, suggest a presence of two muscarinic receptors of high and low sensibility to acetylcholine and a coupled mechanism between muscarinic receptors and vasoconstriction mediated by cycloxygenase (Moraga and Urriola-Urriola, 2014). Our results are partially agreed with previous studies performed in fish shown that acetylcholine induced contraction in all the species studied so far (Small et al., 1990; Olson and Villa, 1991; Miller and Vanhoutte, 1992; Evans and Gunderson, 1998a). 
However, Ach-mediated vasoconstriction suggest that a coupled Ach-COX contraction described in our study in fish is similar to that reported in human hypertension or hypertension model in rats (Vanhoutte et al., 2005; Shi et al., 2008). In order the evaluate the presence of this response we are evaluated in other specie Isacia conceptionis is an abundant represent of our coast. This specie have behaviour from the open coast and deep near of $50 \mathrm{~m}$, live over rocky and sandy bottoms, contraries to the behavior described previously in G.laevifrons. Respect with this, I. conceptionis feeds on small crustaceans such as isopods and amphipods but also on polychaetes and algae (Medina et al., 2004). It geographical distribution in the South American pacific coast since Lobos (06 $24^{\circ}$ ' 48.2" S and $80^{\circ} 51^{\prime} 6.7^{\prime \prime} \mathrm{W}$, Perú) to Talcahuano (36 $43^{\circ} 30^{\prime}$ ' S and $73^{\circ} 6$ ' 40" W, Chile) (Sánchez, 1997). Considering that ambient conditions are stable, we can indicate that have a minor than stress condition in comparison with G.laevifrons. In respect, we proposed that the marine fish (Isacia conceptionis) of open coast, could be express an acetylcholine pathway of lower vasoconstriction response. Our objective is determining the role of acetylcholine pathway in the vascular function in a marine fish.

\section{Material and Methods}

\subsection{Animals}

Six juvenile I.conceptionis were extracted of the Totoralillo bay ( $30^{\circ} 17^{\prime} \mathrm{S}, 71^{\circ} 31^{\prime} \mathrm{W}$ ) south of Coquimbo, Chile. All specimens were taken to the laboratory at the Universidad Católica del Norte and maintained for 3-5 days in filtered recirculation containers of fresh water at $15^{\circ} \mathrm{C}$. Afterward, corporal mass ( $150 \pm 10 \mathrm{~g})$ and longitude oraltail $(21 \pm 0.8 \mathrm{~cm})$ were measured for each specimen. Prior to experimentation, each specimen was anaesthetized with benzocaine (1:1000) added to the container to transport and sacrificed by decapitation.

\subsection{Bath organ physiology}

After decapitation, arterial vessels were carefully dissected from the following areas: branchial afferent (ABA), branchial efferent (EBA), dorsal (DA) and mesenteric (MA) and placed in cold $\left(4^{\circ} \mathrm{C}\right)$ physiological saline solution (PSS). The PSS contained (in $\mathrm{g} / \mathrm{L}$ ): $\mathrm{NaCl}$ 7.37, $\mathrm{KCl} 0.31, \mathrm{KH}_{2} \mathrm{PO}_{4} 0.46, \mathrm{Na}_{2} \mathrm{HPO}_{4} 2.02, \mathrm{MgSO}_{4}$ 0.14, $\mathrm{CaCl}_{2} 0.1$, glucose 0.9 with $\mathrm{pH}$ adjusted to 7.8 (Olson and Villa, 1991). Individual arterial ring segments of $2 \mathrm{~mm}$ length were mounted in a four channel small vessel wire myograph (model 610M Danish Myotech, Denmark). The vessels were threaded onto two tungsten wires of $40 \mu \mathrm{m}$ in diameter and attached to a force transducer and a micrometer for isometric measurements. All signals were acquired by a system acquisition (Powerlab 8sp, ADInstrument, Australia) and the data collected on a personal computer for further analysis. After mounting the rings, the arterial segments were incubated in PSS at $15^{\circ} \mathrm{C}$ and gassed with air for $30 \mathrm{~min}$. Each vessel segment was stretched to its optimal diameter, i.e. the diameter at which it developed a contraction response to PSS- $\mathrm{K}^{+}$, using a diameter-tension protocol as previously described for mammalian small arteries (Stassen et al., 1997). In this way, the myograph permitted direct measurement of vessel wall tension while the internal diameter was controlled.

Following an equilibration period of at least $30 \mathrm{~min}$, doses response curves (DRC) were performed for $\mathrm{KCl}$ (5.6-125 mM) and the cholinergic agonist acetylcholine (Ach) at concentrations ranging from $10^{-13}$ at $10^{-3} \mathrm{~mol} / \mathrm{L}$. Afterward, DRC to Ach were performed in vessels preincubated for $30 \mathrm{~min}$ with Atropine (At, $10^{-5} \mathrm{M}$ ), an Ach receptor antagonist; and indomethacin (IND, $10^{-5} \mathrm{M}$ ), a cyclooxygenase (COX) inhibitor. Between experiments, the arterial preparations were allowed to recover for at least 30-60 min to return to resting basal tension.

For the PSS-K ${ }^{+}$solution $(125 \mathrm{mM} \mathrm{KCl}), \mathrm{NaCl}$ was replaced by an equimolar amount of $\mathrm{KCl}$. All chemicals were reagent grade and purchased from Sigma Chemical (St Louis, MO, USA). The following drugs used in the study: Ach, At and IND were purchased from Sigma Chemical (St Louis, MO, USA).

\subsection{Data analysis and statistics}

DRC were analyzed in terms of maximal response (Rmax), sensitivity $\left(\mathrm{EC}_{50}\right.$ or $\left.\mathrm{pEC}_{50}\right)$ to different contractile agents by fitting the individual data with a nonlinear sigmoid regression curve (Prism 4.0, Graphpad, San Diego, CA, USA). Rmax was expressed as $(\mathrm{N} / \mathrm{m})$. Sensitivity was expressed as $\mathrm{EC}_{50}$ (the concentration of agonist at which $50 \%$ of Rmax was obtained) or as $\mathrm{pEC}_{50}\left(-\operatorname{logEC} \mathrm{C}_{50}\right)$.

All results were expressed as mean \pm SEM. A two way ANOVA for repeated measurements was used for statistical analysis of physiological variables. Differences were considered significant when $p<0.05$ (Primer of Biostatistical v 3.0, Mc Graw Hill).

\section{Results}

The calculated internal diameter for all arteries is shown in Table 1, resume an optimal diameter determined in each arteries segments of each vascular territories were of a similar internal diameter.

\subsection{Response to potassium chloride $(\mathrm{KCl})$}

Table 2 provides a summary for the parameter $\mathrm{EC}_{50}$ and Rmax obtained from the analysis of the arterial response curves. No differences were observed in the $\mathrm{EC}_{50}$ in any of the arteries evaluated. In contrast, Rmax increased significantly in the DA and ABA when compared to those obtained from MA and EBA.

Table 1. Optimal diameter in arterial vessel of I. conceptionis.

\begin{tabular}{cccc}
\hline ABA & EBA & DA & MA \\
\hline $425 \pm 83$ & $430 \pm 44$ & $408 \pm 98$ & $406 \pm 88$ \\
$(6)$ & $(6)$ & $(6)$ & $(6)$ \\
\hline
\end{tabular}

Values represent an optimal diameter in $\mu \mathrm{m}$ and were expressed such as mean \pm S.E.M. (n). Abbreviations represent: afferent branchial artery (ABA); efferent branchial artery (EBA); mesenteric artery (MA) and dorsal artery (DA). 
Table 2. Doses response curves in several vascular bed of I.conceptionis.

\begin{tabular}{|c|c|c|c|c|}
\hline & ABA & EBA & DA & MA \\
\hline \multicolumn{5}{|l|}{ CCR-K ${ }^{+}$} \\
\hline $\mathrm{EC}_{50}(\mathrm{mM})$ & $12.8 \pm 2.3$ & $14.9 \pm 2.3$ & $16.4 \pm 2.6$ & $18.2 \pm 1.8$ \\
\hline $\operatorname{Rmax}(\mathrm{N} / \mathrm{m})$ & $2.14 \pm 0.09$ & $1.47 \pm 0.03 *$ & $2.18 \pm 0.04$ & $1.56 \pm 0.04 *$ \\
\hline \multicolumn{5}{|l|}{ CCR-Ach } \\
\hline $\mathrm{pEC}_{50}(\mathrm{mM})$ & $-7.34 \pm 0.28 * *$ & $-5.94 \pm 0.12$ & $-5.9 \pm 0.17$ & $-5.92 \pm 0.03$ \\
\hline $\operatorname{Rmax}(\mathrm{N} / \mathrm{m})$ & $5.98 \pm 0.38 * *$ & $3.93 \pm 0.21$ & $3.93 \pm 0.2$ & $1.46 \pm 0.02 \dagger$ \\
\hline \multicolumn{5}{|l|}{ CCR-Atrop } \\
\hline $\mathrm{pEC}_{50}(\mathrm{mM})$ & $-4.17 \pm 0.06$ & $-4.86 \pm 0.18$ & $0 \pm 0 \ddagger$ & $-4.41 \pm 0.22$ \\
\hline $\operatorname{Rmax}(\mathrm{N} / \mathrm{m})$ & $0.41 \pm 0.01$ & $0.26 \pm 0.01$ & $0 \pm 0 \S$ & $0.01 \pm 0.01$ \\
\hline \multicolumn{5}{|l|}{ CCR-INDO } \\
\hline $\mathrm{pEC}_{50}(\mathrm{mM})$ & $-3.93 \pm 0.02$ & $-4.99 \pm 0.12 \dagger \dagger$ & $-3.37 \pm 0.03$ & $-3.88 \pm 0.10$ \\
\hline $\operatorname{Rmax}(\mathrm{N} / \mathrm{m})$ & $4.25 \pm 0.04$ & $0.24 \pm 0.01 \dagger \dagger$ & $3.90 \pm 0.104$ & $0.37 \pm 0.02$ \\
\hline
\end{tabular}

Abbreviations represent: afferent branchial artery (ABA); efferent branchial artery (EBA); mesenteric artery (MA) and dorsal artery (DA). Mean \pm S.E.M. *DA and ABA vs EBA and MA. **ABA vs DA, EBA and MA. $\dagger$ MA vs DA, ABA and EBA. + DA vs $\mathrm{ABA}, \mathrm{EBA}$ and $\mathrm{MA}$. $\S \mathrm{DA}$ vs $\mathrm{ABA}$ and $\mathrm{ABA}$. $\dagger \dagger \mathrm{EBA}$ vs $\mathrm{DA}, \mathrm{ABA}$ and $\mathrm{MA}(\mathrm{P}<0.05)$.

\subsection{Responses to acetylcholine}

Comparison of all vascular beds showed that ABA had a higher tension to Ach (Figure 1). DRC revealed a pattern of higher sensitivity with lower doses $\left(10^{-10}-10^{-8} \mathrm{M}\right)$ of Ach and lower sensitivity with higher doses $\left(10^{-6}-10^{-3} \mathrm{M}\right)$ of Ach in ABA and minor magnitude in DA. Lower concentrations of Ach produced an increase in tension near to $38 \%$ of the maximal response in these vessels. Table 2 summarizes the $\mathrm{pEC}_{50}$ and Rmax values obtained from analysis of the arterial curves. A major $\mathrm{pEC}_{50}$ was observed in $\mathrm{ABA}$ as compared to EBA and MA. However, a higher Rmax was found in the $\mathrm{ABA}$ as compared to those observed in the EBA, MA and DA $(p<0.05)$. Furthermore, EBA and DA as a major Rmax than MA (Table 2).

\subsection{Response blockade with Atropine}

In order to evaluate if the arterial contraction observed in the presence of Ach was blocked with At $\left(10^{-5} \mathrm{M}\right)$, DRC to Ach were performed in all arterial vessels. The data shows that the contractions induced by ACh were abolished in the presence of At in all vessels studied. Table 2, summarizes the $\mathrm{pEC}_{50}$ and Rmax values obtained from analysis of the arterial curves.

\subsection{Response blockade with IND}

In order to evaluate the mechanism of contraction induced by Ach, we blocked with $I N D\left(10^{-5} \mathrm{M}\right)$ and DRC to Ach were performed in all arterial vessels. Contraction induced by Ach was abolished in presence of IND, in EBA and AM. In contrast, Rmax was maintained to ABA and DA. Table 2 summarizes the $\mathrm{pEC}_{50}$ and Rmax values obtained from analysis of the arterial curves.

\section{Discussion}

Our study demonstrates that marine fish I. conceptionis possess a vasoconstrictor mechanism mediated by Ach coupled to cyclooxygenase pathway. Furthermore, suggest the presence of two muscarinic receptors: one high of

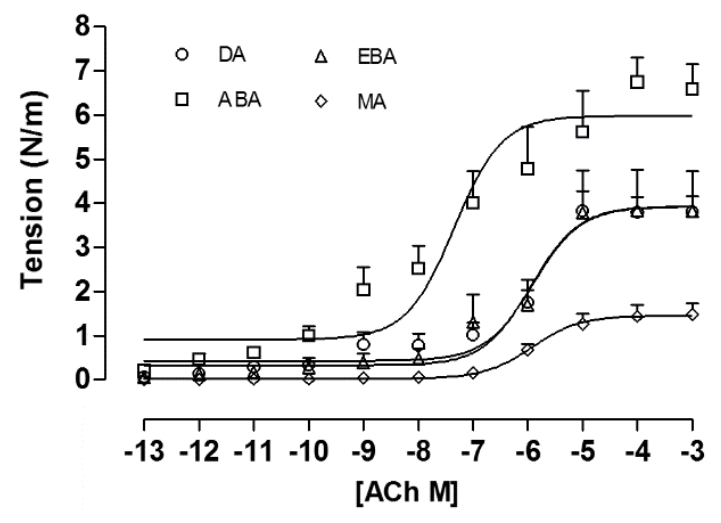

Figure 1. Acetylcholine dose-response curves of isolated rings from: afferent branchial artery (ABA; open squares); efferent branchial artery (EBA, open triangle); mesenteric artery (MA, open rhombus) and dorsal artery (DA, open circles). Each point represents the mean \pm S.E.M.

sensitivity and a second of lower sensitivity coupled to different mechanisms of activation, only in the ABA and DA. By other way, suggest functionally presence on one muscarinic receptor in EBA and MA territories.

\subsection{Vascular response to acetylcholine}

Our results show that all vessels studied (ABA, EBA, MA and DA) express a vasoconstriction mediated by Ach.

The vasoconstriction observed in I. conceptionis suggests the presence of two receptor populations present in the ABA and DA. The first response was characterized by a high sensitivity to a range of $10^{-10}$ to $10^{-8} \mathrm{M}$ of Ach; this response was $38 \%$ of the maximum response observed only in ABA and DA. These response of high sensitivity to Ach was previously described in rings DA, ABA, EBA and MA in isometric studies of vascular reactivity in Girella laevifrons (Moraga and Urriola-Urriola, 2014), also in perfused trunks in cod (Gadus morhua) spleen which displayed contractions to Ach at concentrations 
between $10^{-10}$ and $2 \times 10^{-9} \mathrm{M}$ (Nilsson and Grove, 1974). Head isolation preparations in the icefish Chionodraco hamatus (Pellegrino et al., 2003) exhibited a 30\% maximum contraction response to $\mathrm{Ach}\left(10^{-10} \mathrm{M}\right)$ and this response was blocked by At $\left(10^{-5} \mathrm{M}\right)$. Moreover, in branchial circulation of the eel, a bimodal response to very low concentrations of Ach $\left(10^{-12}-10^{-10} \mathrm{M}\right)$ and a dilation response at higher concentrations which produced a contraction, were both blocked by atropine $\left(10^{-5} \mathrm{M}\right)$ (Pellegrino et al., 2002). This effect could suggest the presence of two muscarinic receptors with different sensitivities and functions. These first and second response only was observed $\mathrm{ABA}$ in our preparation at concentrations between $10^{-6}$ and $10^{-3}$ is in agreement with a low sensitivity. In our preparation, EBA, MA and DA, we only observe the response equivalent to low sensibility to Ach $\left(10^{-6}\right.$ to $\left.10^{-3} \mathrm{M}\right)$. The range described in our study was similar to that described in vascular ring preparations between the ranges of $10^{-8}$ to $10^{-6} \mathrm{M}$ (coronary, celiac mesenteric, central aorta, efferent branchial artery) in trout (Olson and Villa, 1991; Small et al., 1990) and in the ventral aorta in sharks (Evans and Gunderson, 1998a, b). In addition, all previously described studies found only one component in the CRC to Ach. In our study, both responses (high and low sensitivities) were abolished by the use of At $\left(10^{-5} \mathrm{M}\right)$. This evidence is corroborated by other studies in trout, shark and eel (Nilsson and Grove, 1974; Small et al., 1990; Pellegrino et al., 2002; Pellegrino et al., 2003; Moraga and Urriola-Urriola, 2014), supporting the presence of muscarinic receptors in fish vasculature.

Five muscarinic receptors in vascular smooth muscle have been identified by functional, pharmacological and molecular studies in a variety of fish and mammalian (agnathians, elasmobranch and teleosts) (Hulme et al., 1990; Caulfield, 1993; Eglen et al., 1996; Ehlert et al., 1997; Evans and Gunderson, 1998a). In fish, Ach induced contraction in all the species studied so far (Small et al., 1990; Olson and Villa, 1991; Miller and Vanhoutte, 1992; Evans and Gunderson, 1998a). This contractile response was found even in the presence or absence of endothelium (Olson and Villa, 1991; Miller and Vanhoutte, 1992; Evans and Gunderson, 1998b; Miller and Vanhoutte, 2000). Furthermore, a pharmacological study done in sharks found the presence of functional muscarinic receptors type 1 and 3, and non functional muscarinic receptors types 2 and 4 (Evans and Gunderson, 1998a). By other way, in mammals, Ach induces vascular smooth muscle relaxation by activation of muscarinic receptors expressed in endothelial cells (Furchgott and Zawadzki, 1980). Molecular and pharmacological approach has demonstrated the presence of muscarinic receptors type 1-3 in arterial vessels (Norel et al., 1996; Kawashima and Fujii, 2008). Additionally, studies performed in human pulmonary arteries suggest the presence of muscarinic receptor type 3 in smooth muscle mediating the Ach-induced contraction and muscarinic receptors type 1 are involved in the endotheliumdependent Ach-induced relaxation (Norel et al., 1996). However, Ach-mediated vasoconstriction suggest that a coupled Ach-COX contraction described in our study in fish is similar to that reported in human hypertension or hypertension model in rats (Ge et al., 1995; Vanhoutte et al., 2005; Shi et al., 2008).

\subsection{Acetylcholine-cyclooxygenases vasoconstriction pathway}

Our results demonstrate that the Ach-mediated vasoconstriction in all the vessels studied (ABA, EBA, MA and DA) was abolished with At $\left(10^{-5} \mathrm{M}\right)$, indicating the presence of muscarinic receptors that promote vascular vasoconstriction in marine fish. However, when vessels were blocked by IND $\left(10^{-5} \mathrm{M}\right)$, the high sensitivity Achmediated vasoconstriction, previously described, was practically abolished in all the vessels studied, suggesting a coupling mechanism between activation of muscarinic receptors with the production of vasoconstrictor prostanoids mediated by COX in I. conceptionis. This effect did not modify the low sensitivity Ach-mediated vasoconstriction suggesting that this mechanism is mediated by muscarinic receptors in the vascular smooth muscle present in DA and ABA. In contrast, the low sensitivity Ach-mediated vasoconstriction was abolished in EBA and MA. Strategy to corroborate the participation of endothelium in the response described in our study is performing studies without endothelium in presence or absent of Ach plus COX inhibitor. Unfortunately, this design didn't perform in our study.

In contrast, studies performed in shark (Squalus acanthias) or trout, it has been shown that an endotheliumdependent dilation in the presence of a calcium -ionophore (A-23187) promoted dilation by a prostaglandin and not by NO (Evans and Gunderson, 1998b; Olson and Villa, 1991; Miller and Vanhoutte, 2000) suggesting the presence of dilation mediated by prostanoids (Evans and Gunderson, 1998b; Miller and Vanhoutte, 2000). We proposed that are necessaries performing studies of vascular function that evaluate others mechanisms that could be explain this response, such as nitric oxide, monoxide or $\mathrm{H}_{2} \mathrm{~S}$ role dilation in vascular response in fish (Feng et al., 2007; Dombkowski et al., 2009; Jennings and Donald., 2010).

In conclusion, we propose that the marine fish I. conceptionis have muscarinic receptors type 1 and 3 with one muscarinic receptor having a high sensitivity that could be located in the endothelium coupled to COX that produce a prostanoid vasoconstrictor, and another muscarinic receptor having a low sensitivity located in the vascular smooth muscle. However, the type of muscarinic receptor and mechanisms underlying this response still needs to be evaluated.

\section{Acknowledgements}

We are grateful to technical assistance mr. Hervis Galleguillos and students of medicine mss Carolina Norero, Daniela Gonzalez, Natalia Soto and Marietta Nuñez that collaborate in the experiments. This research was partially supported by grant Bicentenario \# 31101042 and DGIP. 


\section{References}

CAULFIELD, MP., 1993. Muscarinic receptors - characterization, coupling and function. Pharmacology \& Therapeutics, vol. 58, no. 3, p. 319-379. http://dx.doi.org/10.1016/0163-7258(93)90027-B. PMid:7504306

DOMBKOWSKI, RA., WHITFIELD, NL., MOTTERLINI, R., GAO, Y. and OLSON, KR., 2009. Effects of carbon monoxide on trout and lamprey vessels. American Journal of Physiology. Regulatory, Integrative and Comparative Physiology, vol. 296, no. 1, p. R141-R149. http://dx.doi.org/10.1152/ajpregu.90507.2008. PMid:19005018

EGLEN, RM., HEGDE, SS. and WATSON, N., 1996. Muscarinic receptor subtypes and smooth muscle function. Pharmacological Reviews, vol. 48, no. 4, p. 531-565. PMid:8981565.

EHLERT, FJ., OSTROM, RS. and SAWYER, GW., 1997. Subtypes of the muscarinic receptor in smooth muscle. Life Sciences, vol. 61 , no. 18 , p. 1729-1740. http://dx.doi.org/10.1016/S00243205(97)00433-5. PMid:9365220

EVANS, DH. and GUNDERSON, MP., 1998a. Functional characterization of a muscarinic receptor in the smooth muscle of the shark (Squalus acanthias). Experimental. Biology Online, vol. 3 , p. 3 .

EVANS, DH. and GUNDERSON, MP., 1998b. A prostaglandin, not NO, mediates endothelium-dependent dilation in ventral aorta of shark (Squalus acanthias). The American Journal of Physiology, vol. 274, no. 4 Pt 2, p. R1050-R1057. PMid:9575968.

FENG, J., YANO, K., MONAHAN-EARLEY, R., MORGAN, ES., DVORAK, AM., SELLKE, FW. and AIRD, WC., 2007. Vascular bed-specific endothelium-dependent vasomomotor relaxation in the hagfish, Myxine glutinosa. American Journal of Physiology - Regulatory, Integrative and Comparative Physiology, vol. 293, p. R894-R900.

FURCHGOTT, RF. and ZAWADZKI, JV., 1980. The obligatory role of the endothelial cells in the relaxation of arterial smooth muscle by acetylcholine. Nature, vol. 288, p. 373-376.

GE, T., HUGHES, H., JUNQUERO, DC., WU, KK., VANHOUTTE, PM. and BOULANGER, CM., 1995. Endothelium-dependent contractions are associated with both augmented expression of prostaglandin $\mathrm{H}$ synthase-1 and hypersensitivity to prostaglandin H2 in the SHR aorta. Circulation Research, vol. 76, no. 6, p. 10031010. http://dx.doi.org/10.1161/01.RES.76.6.1003. PMid:7758154

JENNINGS, BL. and DONALD, JA., 2010. Mechanisms of nitric oxide-mediated, neurogenic vasodilation in mesenteric resistance arteries of toad Bufo marinus. American Journal of Physiology - Regulatory, Integrative and Comparative Physiology, vol. 298, p. R767-R775,

HULME, EC., BIRDSALL, NJM. and BUCKLEY, NJ., 1990. Muscarinic receptors subtypes. Annual Review of Pharmacology and Toxicology, vol. 30, p. 633-673.

KAWASHIMA, K. and FUJII, T., 2008. Basic and clinical aspects of non-neuronal acetylcholine: overview of non-neuronal cholinergic systems and their biological significance. Journal of Pharmacological Sciences, vol. 106, no. 2, p. 167-173. http:// dx.doi.org/10.1254/jphs.FM0070073. PMid:18285657

MEDINA, M., ARAYA, M. and VEGA, C., 2004. Alimentación y relaciones tróficas de peces costeros de la zona norte de Chile. Invest. Mar, vol. 32, no. 1, p. 33-47. http://dx.doi.org/10.4067/ S0717-71782004000100004.
MILLER, VM. and VANHOUTTE, PM., 1992. Endotheliumdependent vascular responsiveness: evolutionary aspects. In RYAN, US. and RUVANYI, GM. (Eds.). Endothelial regulation of vascular tone. New York: Marcel Dekker Inc. p. 3-20.

MILLER, VM. and VANHOUTTE, PM., 2000. Prostaglandins but not nitric oxide are endothelium-derived relaxing factors in the trout aorta. Acta Pharmacologica Sinica, vol. 21, no. 10, p. 871-876. PMid:11501036.

MORAGA, FA. and URRIOLA-URRIOLA, N., 2014. Vascular function in arteries of intertidal fish Girella laevifrons (Kyphosidae). Brazilian Journal of Biology, vol. 74, no. 3, p. 739-743. PMid: 25296227.

NILSSON, S. and GROVE, DJ., 1974. Adrenergic and cholinergic innervation of the spleen of the cod: Gadus morhua. European Journal of Pharmacology, vol. 28, no. 1, p. 135-143. http://dx.doi. org/10.1016/0014-2999(74)90124-1. PMid:4430318

NOREL, X., WALCH, L., COSTANTINO, M., LABAT, C., GORENNE, I., DULMET, E., ROSSI, F. and BRINK, C., 1996. M1 and M3 muscarinic receptors in human pulmonary arteries. British Journal of Pharmacology, vol. 119, no. 1, p. 149-157. http:// dx.doi.org/10.1111/j.1476-5381.1996.tb15688.x. PMid:8872368

OLSON, KR. and VILLA, J., 1991. Evidence against endotheliumderived relaxing factor(s) in trout vessel. The American Journal of Physiology, vol. 260, no. 29, p. 925-933.

PELLEGRINO, D., SPROVIERI, E., MAZZA, R., RANDALL, DJ. and TOTA, B., 2002. Nitric oxide-cGMP-mediated vasoconstriction and effects of acetylcholine in the branchial circulation of the eel. Comparative Biochemistry and Physiology. Part A, Molecular \& Integrative Physiology, vol. 132, no. 2, p. 447-457. http://dx.doi. org/10.1016/S1095-6433(02)00082-X. PMid:12020661

PELlEGRINO, D., ACIERNO, R. and TOTA, B., 2003. Control of cardiovascular function in the icefish Chionodraco hamatus: involvement of serotonin and nitric oxide. Comparative Biochemistry and Physiology. Part A, Molecular \& Integrative Physiology, vol. 134, no. 2, p. 471-480. http://dx.doi.org/10.1016/ S1095-6433(02)00324-0. PMid:12547277

PULGAR, J., BOZINOVIC, F. and OJEDA, FP., 1999. Behavioral thermoregulation in the intertidal fish Girella laevifrons (Kyphosidae): the effect of starvation. Marine and Freshwater Behaviour and Physiology, vol. 32, no. 1, p. 27-38. http://dx.doi. org/10.1080/10236249909379035.

SHI, Y., MAN, RY. and VANHOUTTE, PM., 2008. Two isoforms of cyclooxygenase contribute to augmented endotheliumdependent contractions in femoral arteries of 1-year-old rats. Acta Pharmacologica Sinica, vol. 29, no. 2, p. 185-192. http:// dx.doi.org/10.1111/j.1745-7254.2008.00749.x. PMid:18215347

SÁNCHEZ, AC., 1997. Listado taxonomico de las especies marinas identificadas en los océanos Pacífico y Atlántico (Caribe) de Nicaragua. Managua: Ministerio de Economía y Desarrollo/ MEDE PESCA. 28 p.

SMALL, SA., MACDONALD, C. and FARRELL, AP., 1990. Vascular reactivity of the coronary artery in rainbow trout (Oncorhynchus mykiss). The American Journal of Physiology, vol. 258, no. 6 Pt 2, p. R1402-R1410. PMid:2360689.

STASSEN, FR., RAAT, NJ., BROUWERS-CEILER, DL., FAZZI, GE., SMITS, JF. and DE MEY, JG., 1997. Angiotensin II induces media hypertrophy and hyperreactivity in mesenteric but not epigastric small arteries of the rat. Journal of Vascular Research, vol. 34, no. 4, p. 289-297. http://dx.doi.org/10.1159/000159236. PMid:9256089 
URRIOLA-URRIOLA, N. and MORAGA, FA., 2008. Comparative study of cholinergic responses in doral artery between intertidal fish Girella laevifrons and subtidal fish Isacia conceptionis. Revista de Farmacologia de Chile, vol. 1, no. 1, p. 94.
VANHOUTTE, PM., FELETOU, M. and TADDEI, S., 2005. Endothelium-dependent contractions in hypertension. British Journal of Pharmacology, vol. 144, no. 4, p. 449-458. http:// dx.doi.org/10.1038/sj.bjp.0706042. PMid:15655530 